https://www.scilook.eu/index.php/slif/article/view/slif16-031 DOI: 10.30888/2415-7538.2020-16-01-031

\title{
THE DEVELOPMENT OF PROBLEM BASED LEARNING GEOGRAPHIC MODULE TO IMPROVE STUDENT CRITICAL THINKING
}

Mesiyanto

Magister Program of Social Studies, Faculty of Teacher Training and Education, Lampung University, Bandar Lampung

\begin{abstract}
Effective Learning method is needed to support student learning development. One of the best ways to give an effective learning is making a supportive system of learning and teaching. This study aiming on geographic subject textbook with problem based learning method. The purpose of this study is to analyze problem based learning as geographic subject textbook whether by its eligibility level, effectiveness level or it ability to help student in order to make them having more critical thinking. To collecting the data, this study uses experimental research design as comparison of pre-test and post-test results (one group pre-test and post-test). The result of this study indicates that, there is an improvement on third grade student of Al-Kautsar High school of Bandar Lampung. They have become more critical on geographic subject. Thus, it can be concluded that problem based learning method is effective to improve student of Al-Kautsar High school critical thinking as they have become more critics and actives.
\end{abstract}

Key Words: problem based learning, research and development, Experimental research

1. Introduction

Teachers are professional worker; they are protected by law and have the right to get professional allowances from the government. As professional worker, teacher has to have an awareness and responsibility on developing their competences whether it pedagogical competence, personality competence, social competence or professional competence. One of indicator development professional competences is teacher's ability to arrange lesson material, lesson plan and their teaching content contains the right information, relate to the current issue, thus they can help student to understanding concept of learning material. As a form of developing professional of every teacher, teacher has to improve an independent teaching material which has to be contextual, innovative and related to what their students need therefore it can give positive influence toward students learning affectivity.

Based on the evaluation result by Directorate of High School Development of National Education Ministry, it was found that many teachers has not been able to developing their teaching material independently. Besides, most of teachers tend to be relying more on the textbook or teaching materials compiled by others. That is happen because they are still lack of awareness and they still did not know the importance of making their own teaching materials as what students need, the benefit of teaching materials and teachers still lack of understanding about mechanism of the right lesson materials (Depdiknas, 2010). Same statements sated by Prastowo (2014), reality of our education still learning using conventional method which they get the teaching material that has been ready before, they just need to purchase it and use it instantly without an effort of compile it by themselves. Therefore, it is a big possibility of making non contextual, monotone, and not interesting learning materials.

There is a realistic condition in Al Kautsar High school Bandar Lampung based on study result through interview with the vice headmaster related to school 
curriculum, it indicates that all the teaching material requirements for teacher and students are entirely provided by school with cooperation of textbook publisher. Details for learning book which become teaching materials are first, second and third grade of high school and it using textbook as teaching materials. Related to teacher facilities on making teaching materials, school can be one of factor of teacher having lack of awareness on constructing teaching materials that relate to students need.

Observation data and questionnaire for two teachers on Geographic subject in $\mathrm{Al}$ Kautsar High school Bandar Lampung indicated that learning process in class with two geographic subject teacher still using textbook or not using independent teaching material by subject teacher. This condition makes the teaching materials they used are not interesting, monotone and not suitable for what students need. Creativities of Geographic teacher on developing an innovative, creative, contextual and appropriate for student development level. Thus through geographic subject, student expected to improve their critical thinking.

Based on the explanation above, an innovative teaching material needs to be developed. Beside, teaching material also needs to be contextual and appropriate for student. Subject teachers can help student to have proper learning by making their own independent teaching materials, therefore it will suitable for their current competencies. The most suitable development of teaching materials in SMA Al Kautsar Bandar Lampung is module textbook. Teaching materials development in format of module textbook can be reference of written learning which will make student easier to understand the materials compatible with their level and needs. That development of module textbook is expected to become inspiration for other subject teachers on their mission making appropriate materials for student.Basic consideration of developing teaching materials in format of module textbook, because textbook has some benefit such as: 1) focused on student individual ability, and it will make students more independent and having more responsibility, 2) there is control over student learning outcomes by using competence standard in each module that must be achieved by student, 3) curriculum relevance indicated by their goals and how they achieve their goals, thus student will understand their process and results (Mulyasa, 2003).

Moreover, with module, student ability of critical thinking can be developed, therefore students required not only having ability to remember, understand and applying it. But student also required havingability in analyzing the relationship between phenomenon in village and town and interaction among all area within all the effect of it phenomenon. Other consideration pointing out at the studied material on basic competence is more dynamic since the subject will always developed along with rapid development of science and technology which makes this material become more interesting to learn. This problem based learning more involving student role and collaboration rather than teacher's participation. Hence, teacher will participate as learning facilitator, material organizing and evaluating the process.

\section{Research Methodology}

This study using Research and Development methodology. According to Sugiyono (2015)Research and Development is an observation method uses to obtain any certain product and examine the effectiveness of it product. According to Borg 
and M.D Gall cited on Pragito (2009) there are ten stages of Research and Development such as: 1) Research and information collecting, 2) Planning, 3) Develop preliminary form of product, 4) Preliminary field and testing, 5) Main product revision, 6) Main field testing, 7) Operational product revision, 8) Operational field testing, 9) Final product revision, and 10) Dissemination and implementation.

Research and Development uses to develop Geographic subject textbook with problem based learning method and next it can be useful on student learning process which is expected to help student improve their critical thinking.

This study using experimental observation design is an observation method using to observe and looking for the influence of certain attitude toward another in a constrained condition (Sugiyono, 2016). Experimental design uses in this study is module trial of a group pre-test post-test design. This design includes a pre-test measure followed by a treatment and a post-test for a single group (Creswell, 2009).

Design pattern according to Creswell can be seen on figure 1

$$
\mathrm{O}_{1} \text {-..-.-. } \mathrm{X} \text {-...-.-- } \mathrm{O}_{2}
$$

\section{Figure 1 One-Group Pre-test -Post-test Design}

Explanation:

$\mathrm{O} 1=$ Pre-test

$\mathrm{X}=$ Treatment

$\mathrm{O} 2$ = Post-test

This design having pre-test before, thus the result will be more accurate because it compared the result before and after giving a treatment. On the picture above, $\mathrm{X}$ is a treatment gave on research subject which is problem based learning on geographic subject; $\mathrm{O} 1$ is pre-test score before they gave treatment, while $\mathrm{O} 2$ is post-test score after they gave treatment. This study using single variable, describe as: student ability of thinking.

According to Sugiyono (2015:117) population is generalization zone contain of object/subject with certain quality and characteristic determined by researcher to be learned and making a conclusion. Whereas according to Nazir (2014), population is a group of individual with predetermined characteristic.

Al-Kautsar High School Bandar Lampung have study group for their third grade of 11 classes with the details of 7 classes in science study group and 4 classes include as social science. Among all the classes, 5 classes from science taking geography subject and all of social science classes taking geography subject. Based on the consideration of time and cost, researcher includes 4 classes for research population with 64 students from science and 62 students from social science therefore, total population are 126 students.

Based on the opinion above, research sample is a part of population which represents the characteristic of all population. Technic sampling used in this research is nonprobability sampling with sampling systematic. According to Sudarmanto (2013), systematic sampling is a technic of taking research sample using certain order among every population which has been registered and given an order number. Order 
number of systematic sampling can be determined first. Example: taking sample from even numbers, only from odd numbers, only from multiple of four, and else.

In this case, sampling determination using an order number that is multiple of 3 (three). All populations have been sorted based on their ability of critical thinking. Next, student with number 3,6,9,12,15 and else become a research sample. Total sample in this analysis is 42 students.

Data collection technics here are interview, observation, questionnaire and test. Interview used to gain information that related to the current applied curriculum from school and teaching materials from school. Interview data resources are headmaster and vice of headmaster to be asked about curriculum. Observation taken inside geographic classes to gain the data of the application of teaching materials. Questionnaire used to obtain research data which relate to eligibility of module according to media expert, material expert, linguistic expert, small study group and field test. The test taken before learning process (pretest) and after learning process (posttest) it has purpose to know student development on critical thinking after they applying Geographic module with problem based learning.

Data analysis technic has some steps:

1. Validity test and Instrument Reliability

Validity test of question item based using computer based through application program of SimplePAS. This validity test of question item shows that 10 item of questions having a value of $r_{\text {count }}>r_{\text {table }}(5 \%)$ it means that every question is valid. Question number 1,2,5,7,8 having "high" validity. Question number 3,4,9 categorized as "medium" and question number 10 categorized as "low".

Reliability test pointing out at an explanation of instrument can be counted as reliable if those instruments can be used as collecting data tools and in a good condition (Arikunto, 2010). Result of instrument testing, obtained that research instrument having realibility which categorized as "high" therefore research instrument with essay question can be used for measuring student critical ability.

2. Textbook Module Eligibility Analysis

Basic data of analyzing eligibility of module comes from media expert, material expert, linguistic expert, a small group of student and field trial with questionnaire research. Questionnaire sheet that used here is Likert scale standard with five options. Questionnaire data is qualitative; therefore it needs some steps as below:

1) Converting qualitative to quantitative

\begin{tabular}{|l|c|}
\hline \multicolumn{1}{|c|}{ Respondent answer } & Score \\
\hline Really Agree (RA) & 5 \\
\hline Agree (A) & 4 \\
\hline Netral (N) & 3 \\
\hline Disagree (D) & 2 \\
\hline Really Disagree (RD) & 1 \\
\hline
\end{tabular}

2) Calculating score averages from every aspect using formulas by Sukardjo (2005:53) within Zulfri Adhi Wibowo and Mahendra Adhi Nugroho (2015) as described below:

$$
\bar{\chi}=\frac{\sum \chi}{N}
$$


Explanation:

$\bar{\chi}=$ Score Averages

$\sum \chi=$ Total Score

$\mathrm{N}=$ Total Subject

3) Score Averages interpreted in qualitative

\begin{tabular}{|c|l|l|l|}
\hline No & \multicolumn{1}{|c|}{ Formulas } & \multicolumn{1}{c|}{ Range } & \multicolumn{1}{c|}{ Category } \\
\hline 1 & $\mathrm{X}>\bar{X}+1,80 \mathrm{Sbi}$ & $\mathrm{X}>4,20$ & $\begin{array}{l}\text { Really } \\
\text { Appropriate }\end{array}$ \\
\hline 2 & $\begin{array}{l}\bar{X}+0,60 \mathrm{SBi}<\mathrm{X} \leq \\
\bar{X}+1,80 \mathrm{SBi}\end{array}$ & $3,40<\mathrm{X} \leq 4,20$ & Appropriate \\
\hline 3 & $\begin{array}{l}\bar{X}-0,60 \mathrm{SBi}<\mathrm{X} \leq \\
\bar{X}+0,60 \mathrm{SBi}\end{array}$ & $2,60<\mathrm{X} \leq 3,40$ & Normal \\
\hline 4 & $\begin{array}{l}\bar{X}-1,80 \mathrm{SBi}<\mathrm{X} \leq \\
\bar{X}-0,60 \mathrm{SBi}\end{array}$ & $1,80<\mathrm{X} \leq 2,60$ & Inappropriate \\
\hline 5 & $\mathrm{X} \leq \bar{X}-1,80 \mathrm{SBi}$ & $\mathrm{X} \leq 1,80$ & $\begin{array}{l}\text { Really } \\
\text { Inappropriate }\end{array}$ \\
\hline
\end{tabular}

Table 1

\section{N-Gain Trial}

Analyzing data to understand an effectiveness of using problem based learning module as geographic textbook to improve student critical thinking by $\mathrm{N}-\mathrm{Gain}$ or the amount of normalized gain.

Table 2

(Noviyanti, 2017)

\begin{tabular}{|l|l|l|}
\multicolumn{1}{c}{} & N-Gain test result \\
\hline $\begin{array}{c}\text { Normalized Gain } \\
\text { Averages }\end{array}$ & Classification & Effectiveness Level \\
\hline$\langle g\rangle \geq 0,7$ & High & Effective \\
\hline $0,7.\rangle\langle g\rangle \geq 0,3$ & Medium & Quite effective \\
\hline$\langle g\rangle\langle 0,30$ & Low & Less Effective \\
\hline
\end{tabular}

\section{T-Test Trial}

Before testing hypothesis using parametric statistic, prerequisite test analysis should be done first, which was normality and homogeneity test.

Normality test is a prerequisite test analysis. Criteria of this test decision using significance $>0,05$ distributed as normal, and if significance $<0,05$ cannot distributed as normal (Priyatno, 2009).

Homogeneity variant test uses to know whether the samples taken by homogeny or not. The Homogeneity test here uses Levene's test. Levene's test is a test by help of IBM SPSS 16 for windows. Criteria needed for this testif Significance $<0,05$ it indicated as different, while if significance $>0,05$ indicated as similar or homogeny (Priyatno, 2009)

\section{Result And Discussion}

Research data used for analyzing eligibility level of geographic module for problem based learning are developed by validation of media expert, validation of material expert, validation of linguistic expert and limited trial which conducted in nine students by fulfilling questionnaire of textbook effectiveness. Instrument arranged according to all aspects in lesson plan using Likert scale with total scale around 1 to 5 . The average of validation result gain by total validation score divided 
by the number of question on questionnaire.

1. eligibility test result by media expert

This validation done by media expert to know eligibility level of learning process from point of view of learning media.

Table 3.

Validation result of module eligibility by media expert

\begin{tabular}{|l|c|c|c|c|}
\hline \multicolumn{1}{|c|}{ Aspect } & $\begin{array}{c}\text { Total } \\
\text { Score }\end{array}$ & $\begin{array}{c}\text { Total } \\
\text { Question }\end{array}$ & Averages & Category \\
\hline Format & 20 & 5 & 4,00 & Appropriate \\
\hline Organization & 54 & 13 & 4,15 & Appropriate \\
\hline Attraction & 22 & 5 & 4,40 & Very Appropriate \\
\hline $\begin{array}{l}\text { Font style and } \\
\text { size }\end{array}$ & 38 & 9 & 4,22 & Very Appropriate \\
\hline Empty room & 20 & 5 & 4,00 & Appropriate \\
\hline Consistency & 17 & 4 & 4,25 & Very Appropriate \\
\hline Total & 117 & 41 & 4,17 & Appropriate \\
\hline
\end{tabular}

The result signified that geographic module textbook based on problem based learning on spatial structure and village-town interaction according to media expert is appropriate to use as teaching material on learning process.

2. Eligibility test result by Material Expert

This validation applied to know eligibility level of learning process from point of view of learning material and the content of each module textbook. Validation of material expert toward problem based learning geographic module analyzed by doctor from education faculty of Lampung University. Validation instrument for material expert consist of 20 questions which divided on five aspects: self-instruction aspect or possibility of student independent learning (8 number of question), selfcontained aspect or every materials inside the textbook as a whole unity (3 number of questions), stand-alone aspect or independent textbook module do not depends on other material (3 number of questions), adaptive aspect or having an ability for easily adapted in every development of knowledge and technology (2 number of questions) and the last is user friendly aspect or bunch of instruction and information inside the textbook and it helpful for user (4 number of questions).

Eligibility test result by Material Expert

\begin{tabular}{|l|c|c|c|c|}
\hline \multicolumn{1}{|c|}{ Aspects } & $\begin{array}{c}\text { Total } \\
\text { Score }\end{array}$ & $\begin{array}{c}\text { Number of } \\
\text { questions }\end{array}$ & Averages & Categories \\
\hline $\begin{array}{l}\text { Student } \\
\text { Independency } \\
\text { Learning }\end{array}$ & 33 & 8 & 4,13 & Appropriate \\
\hline $\begin{array}{l}\text { Content } \\
\text { Integrity inside } \\
\text { module textbook }\end{array}$ & 11 & 3 & 3,67 & Appropriate \\
\hline $\begin{array}{l}\text { Module } \\
\text { Independency }\end{array}$ & 10 & 3 & 3,33 & Quite Appropriate \\
\hline $\begin{array}{l}\text { Adaptation } \\
\text { ability }\end{array}$ & 8 & 2 & 4,00 & Appropriate \\
\hline $\begin{array}{l}\text { Helpful for } \\
\text { Users or Student }\end{array}$ & 17 & 4 & 4,25 & Very Appropriate \\
\hline Total & 79 & 20 & 3,95 & Appropriate \\
\hline
\end{tabular}


The whole aspect inside module textbook have an average score about 3,95. It explains that according to material expert, geographic textbook module categorized as appropriate teaching materials on spatial structure and village-town interaction subject.

\section{Eligibility test result by Linguistic Expert}

This Validation done by linguistic expert, the purpose is to know the eligibility of module from it languages. This validation was done by linguistic expert with doctor title from Indonesian literature major, faculty of education, Lampung University. Instrument for linguistic expert consist of 13 number of questions and divided into six aspects. Systematic aspects (3 number of questions), communicative aspects (couple number of questions), dialogic and interactive aspects (couple number of questions), suitable for student aspects (couple number of questions), compatible with language rule aspects (couple number of questions) and term, symbol and icon aspects (couple number of questions)

Table 5.

\section{Eligibility test result by Linguistic Expert}

\begin{tabular}{|l|c|c|c|c|}
\hline \multicolumn{1}{|c|}{ Aspects } & $\begin{array}{c}\text { Total } \\
\text { Score }\end{array}$ & $\begin{array}{c}\text { Total Number of } \\
\text { Questions }\end{array}$ & Averages & Categories \\
\hline Systematic & 14 & 3 & 4,67 & Very Appropriate \\
\hline Communicative & 10 & 2 & 5,00 & Very Appropriate \\
\hline $\begin{array}{l}\text { Dialogic and } \\
\text { Interactive }\end{array}$ & 9 & 2 & 4,50 & Very Appropriate \\
\hline $\begin{array}{l}\text { Compatible with } \\
\text { student development }\end{array}$ & 10 & 2 & 5,00 & Very Appropriate \\
\hline Language rules & 8 & 2 & 4,00 & Appropriate \\
\hline Term/Symbol/Icon & 10 & 2 & 5,00 & Very Appropriate \\
\hline Total & 61 & 13 & 4,69 & Very Appropriate \\
\hline
\end{tabular}

Source: 2019 Research Data

Those tables explained that based on linguistic point of view, Geographic is very appropriate for teaching materials on spatial structure and village-town interaction subject.

\section{Limited test result}

Limited test done by 9 students which already have different critical thinking. 3 students categorized as having a very good critical thinking, 3 students with an enough critical thinking and the rest 3 students with less critical thinking.

Table 6.

Limited test results

\begin{tabular}{|l|c|c|c|c|}
\hline \multicolumn{1}{|c|}{ Aspect } & $\begin{array}{c}\text { Total } \\
\text { Score }\end{array}$ & $\begin{array}{c}\text { Total numberof } \\
\text { questions }\end{array}$ & Averages & Categories \\
\hline $\begin{array}{l}\text { Material } \\
\text { presentation }\end{array}$ & 325 & 81 & 4,01 & Appropriate \\
\hline Media/display & 594 & 144 & 4,13 & Layak \\
\hline Learning process & 170 & 45 & 3,78 & Layak \\
\hline Benefit & 99 & 27 & 3,67 & Layak \\
\hline Total & 1.188 & 197 & 4,00 & Layak \\
\hline
\end{tabular}

Whole aspects inside module textbook having an averages of 4,00. This indicates that geographic module is appropriate for teaching materials on spatial 
structure and village-town interaction subject.

\section{Description of Research Data Results}

\section{Module's eligibility}

Geographic Module with problem based learning is appropriate to be used as learning material after being revised with suggestion from media expert, material expert, linguistic expert and students.

\section{Module Usage effectiveness}

Observation result of module usage effectiveness on learning process categorized as medium or can be concluded that module learning on geographic subject with problem based learning is quite effective to improve student critical thinking.

Learning process using module, begin with learning material description of problem based which happen around the student as a material with student as main participant. Here, the learning process is not dominated by teacher. And it will be more interesting, effective and efficient. Furthermore this learning process supported with innovative learning resources and appropriate with students need. Creativity of teacher's learning material have important role to help students achieve their goals. This is because teacher is a significant person to understand students' condition.

Those observation results in line with Prastowo (2014), teacher demanded to be creative in order to make an innovative, variative and interesting learning content and suitable for students' need. Teaching material can help learning process become more captivating and not boring and of course it will help an effective learning process.

\section{Increasing Student Critical Thinking Ability}

Hypothesis test using formulas of $t$ Test (Paired samples $t$-test) counting manually and will be gain the result of $\left(t_{\text {value }}=10,116 \geq t_{\text {table }}=2,02\right)$, therefore $H_{0}$ is rejected. Thus, it can be indicated that there is a difference between student critical thinking before (pre-test) and after learning process (post-test). The results indicate that teaching materials which arranged based on syntax model of Problem Based Learning can improve student critical thinking especially on categories of classification, hypothesis, assumption, analysis, evaluation, and making conclusion.

The result above supported by Margetson (1994) in Rusman (2012) stated that learning process with problem based learning will help student to improve their creativity and having an open mindset, reflective, critical and active learning.

\section{Conclusion and Suggestion}

1. Development of geographic learning with problem based learning on spatial structure and village and town interaction chapter using Research and Development Borg and Gall model is appropriate to use on learning material of third grade students of Al Kautsar High School Bandar Lampung. The first trial or field test using problem based learning after revised got total average of 4,27 which categorize as an appropriate material.

2. The use of geographic textbook with problem based learning on its needed chapter proven to be quite effective to improve student critical thinking on third grade student of Al Kautsar High School Bandar Lampung with gain score of 0,343 or categorized as medium.

3. There is a difference of student critical thinking before and after they learn 
using problem based learning with result of $\mathrm{t}$ trial (Paired samples t-test) of 10,116.

Based on the conclusions above, researcher give some suggestion such as, school needs to support every teacher by giving them chance and facilities for all subject teacher. Problem based learning proven to be effective on learning process, thus it can be the basic material to develop another teaching material by teacher. Geographic textbook combined with Problem based learning model will help to improve student critical thinking; therefore it can be the basic of other learning models on curriculum 2013.

\section{References}

1. Arikunto, S. (2010). Prosedur Penelitian Pendekatan Praktik Edisi Revisi VI. In Rineka Cipta.

2. Creswell, J. W. (2009). Research Design: Qualitative, Quantitative and Mixed Approaches (3rd Edition). In Research Design: Qualitative, Quantitative, and Mixed Methods Approaches. https://doi.org/10.2307/1523157

3. Depdiknas. (2010). Seri Petunjuk Teknis Pelaksanaan Pembelajaran dalam Implementasi KTSP di SMA. Jakarta: Kemendiknas.

4. Mulyasa. (2003). Kurikulum Berbasis Kompetensi: Konsep, Karakteristik, dan Implementasi. Bandung: Remaja Rosdakarya.

5. Nazir. (2004). Metode Penelitian. Metode Penelitian.

6. Noviyanti, R. (2017). Pengembangan Modul Berbasis Problem Based Learning pada Materi Pencemaran Lingkungan untuk Pembentukan Kemampuan Berpikir Kritis Siswa Sekolah Menengah atas di Lampung Timur. Lampung University.

7. Pargito. (2009). Penelitian dan Pengembangan Bidang Pendidikan. Lampung University.

8. Prastowo, A. (2014). Panduan Kreatif Membuat Bahan Ajar Inovatif. PLoS Medicine. https://doi.org/10.1016/j.burns.2014.02.013

9. Priyatno, D. (2009). SPSS untuk Analisis Korelasi, Regresi, dan Multivariate. Yogyakarta: Gava Media. https://doi.org/10.1016/j.freeradbiomed.2008.11.016

10. Rusman. (2012). Model-model Pembelajaran Mengembangkan Profesionalisme Guru. In Jakarta: Rajawali Pers.

11. Sudarmanto, \& Gunawan, R. (2013). Statistik Terapan Berbasis Komputer. Jakarta: Mitra Wacana Media.

12. Sugiyono, P. D. metode penelitian kuantitatif, kualitatif,dan R\&D. , Alfabeta, cv. (2016).

13. Wibowo, Z. A., \& Nugroho, M. A. (2015). PENGEMBANGAN MEDIA PEMBELAJARAN GAME TAX ADMINISTRATION MILLIONAIRE QUIZ UNTUK MATA PELAJARAN ADMINISTRASI PAJAK. Jurnal Pendidikan Akuntansi Indonesia. https://doi.org/10.21831/jpai.v13i1.5192 